\title{
Phaeoacremonium species associated with olive wilt and decline in southern Italy
}

\author{
Antonia Carlucci • F. Lops • F. Cibelli • \\ M. L. Raimondo
}

Accepted: 7 December 2014 / Published online: 20 December 2014

(C) The Author(s) 2014. This article is published with open access at Springerlink.com

\begin{abstract}
Six Phaeoacremonium species (spp.) were isolated from symptomatic wood of olive trees (Olea europea) in Apulia (southern Italy) that showed crown wilt and twig and branch dieback. These Phaeoacremonium spp. were identified according to their morphological characteristics and by analyses of partial sequences of the actin and $\beta$-tubulin genes. Combining these cultural, morphological and molecular data, three Phaeoacremonium spp. were isolated that are already known to be responsible for severe decline of olive in Apulia, Phaeoacremonium aleophilum, Phaeoacremonium alvesii and Phaeoacremonium parasiticum, together with three other Phaeoacremonium spp. that are associated for the first time with wilt, decline and dieback of olive orchards in Italy and worldwide: Phaeoacremonium italicum, Phaeoacremonium sicilianum and Phaeoacremonium scolyti. To understand and to confirm their involvement in wilt and decline of olive trees, pathogenicity assays were performed on shoots of young olive plants. The data indicate that all six of these Phaeoacremonium spp. can cause discolouration, necrotic wood, and death of shoots, although different levels of virulence were observed, with Pm. italicum, Pm. aleophilum and Pm. sicilianum producing greater necrotic lesions than the other Phaeoacremonium spp. investigated here.
\end{abstract}

A. Carlucci $(\bowtie) \cdot$ F. Lops $\cdot$ F. Cibelli $\cdot$ M. L. Raimondo Dipartimento di Scienze Agrarie, degli Alimenti e dell'Ambiente, Università degli Studi di Foggia,

Via Napoli, 25, 71122 Foggia, Italy

e-mail: antonia.carlucci@unifg.it
Keywords Phaeoacremonium spp · Actin · $\beta$-tubulin . Decline $\cdot$ Olive

\section{Introduction}

In historical times, the olive tree (Olea europea L.) spread from its native Asia Minor, from the Paleolithic period (Salavert 2008) through the early Neolithic period (Galili et al. 1997). Olive cultivation is considered to have then begun during the Chalcolithic period (Neef 1990; Zohary and Spiegel-Roy 1975). Studies conducted by Van Zeist (1980) suggested that olive cultivation gradually moved from the east to the west until it reached the Mediterranean area, and was taken to Greece around 2500 BC by the Phoenicians. Subsequently, during the Roman Empire, the Romans promoted the diffusion of the olive tree into some regions of southern Italy, including Apulia (Terral et al. 2004). After the discovery of the Americas, the spread of olive cultivation continued into Peru, Argentina, Chile and Uruguay, and northwards to the coastal regions of Mexico and to the United States, where it found an ideal environment in southern California. As the olive fruit and oil have been always more appreciated and as their consumption has increased, olive cultivation became more widespread in South Africa and along the coast of Australia, where it was introduced by Italian and Greek immigrations, and also in New Zealand and China. Hence, the olive tree is of major economic importance in many countries. The European Union is the leading world producer of olive oil and drupes, while 
also being the leading consumer of about $70 \%$ of the world produce (Food and Agriculture Organisation of the United Nations 2013).

Agosteo (2011) investigated olive diseases through a historical account, and reported that in De Res Rustica, Columella (4-70 D.C.) described the olive as a frugal, resistant and imperishable plant. This account further indicated that when left to itself, as often happened over the centuries, the olive tree was able to survive, and that with the use of charcoal burners at the base of the trunk, it could returned to its spontaneous state, as with the wild olive in the Mediterranean woodland, where it emulated oleaster and was found together with oak, lentisk, broom and rosemary. During this period, agricultural problems occurred with olive cultivation, such as wilting, loss of flowers, and lack of fruit production, although these were initially not investigated. In Italy in 1936 (Agosteo 2011), three reasons were given regarding the agricultural problems of olive plants: the cultural lack of care of the olive orchards; their spontaneous origin; and the long age and size of the trees. The age and the perpetual lack of care had made the olive tree a plant in a constant state of disease.

Investigations into plant pathology to identify the causal agents of olive diseases began to take their first steps as an independent science only in the second half of the 1800 's, when it was necessary to find a remedy to protect the agricultural yields. Although olive trees were considered to be very resistant to environment injuries, including biotic agents, several biotic entities were able to damage the healthy olive tree. The main fungal diseases that affected olives included: leaf diseases such as peacock spot, caused by Spilocaea oleaginaea; infectious leaf burn, caused by Martamyces panizzei (De Not.) Minter; cercospora leaf spot, caused by Pseudocercospora cladosporioides (Sacc.) (Braun 1993); and vascular diseases such as tracheomycosis, caused by Verticillium spp.; and anthracnose, caused by Colletotrichum species (spp.) and Botryosphaeriaceae spp. (Talhinhas et al. 2005; Moral et al. 2008).

More recently, decline, dieback and canker diseases on olives have acquired great importance worldwide. In the literature, different fungal species have been associated with olive decline and dieback. Rumbos (1988, 1993) reported on Eutypa lata and Cytospora oleina in Greece, and Tosi and Natalini (2009) and Tosi and Zazzerini (1994) reported on Phoma incompta and E. lata in Italy. Phoma incompta was also associated with olive dieback by Ivic et al. (2010) in Croatia, and by Rhouma et al. (2010) in Tunisia. Botryosphaeriaceae spp. have been reported to be associated with olive branch dieback, canker and decline, although they are primarily involved in olive fruit rot (Chattaoui et al. 2011; Moral et al. 2008; Phillips et al. 2005). The main Botryosphaeriaceae spp. from olive wood are: Botryosphaeria dothidea, Diplodia mutila, D. seriata, Dothiorella iberica, Neofusicoccum mediteraneum, and Lasiodiplodia theobromae in California (Moral et al. 2010; Úrbez-Torres et al. 2013); Botryosphaeria ribis in Spain (Romero et al. 2005); D. seriata in Croatia (Kaliterna et al. 2012); and D. mutila, L. theobromae and Neofusicoccum parvum in Italy (Carlucci et al. 2013b).

Another fungus, Pleurostomophora richardsiae, was also recently associated with brown wood streaking and canker of olive trees in Italy for the first time (Carlucci et al. 2013b). Recently, a severe decline of olives occurred in Italy characterized by a rapid dieback of shoots, twigs and branches, and dark yellowing and browning of the leaf tips that was followed by death of the olive plant. In southern Italy, Nigro et al. (2013) isolated the following from symptomatic tissues: Phaeomoniella chlamydospora, Phaeoacremonium aleophilum, Phaeoacremonium alvesii, Phaeoacremonium parasiticum and Phaeoacremonium rubrigenum. The last three of these fungi were reported for the first time from olives in Italy.

The aim of the present study was to identify and characterise the fungi associated with vascular discolouration observed in xylem tissues of declining olive plants in Apulia, and to use pathogenicity tests to determine if they are responsible for olive decline.

\section{Materials and methods}

Fungal isolations

During a field survey carried out from March 2012 to December 2013 across several olive orchards of the Foggia province in southern Italy, generalised wilt and decline symptoms were seen, and a large number of samples from the base of the trunk, and the trunks and branches were collected. As the olive orchards visited were of different ages (from 24 to over 100 years old), the samples were distinguished on the basis of age of the trees, while no distinction was made regarding the cultivar. The samples were collected from a total of 62 symptomatic olive plants ( 33 plants over 50 years old, and 29 plants under 50 years old), which showed 
external and internal symptoms on the olive trunks, branches and stems: first, wilting and dieback of entire and/or part of the crown, with depressed browning areas and brown streaking under the bark of the trunk and branches (in longitudinal section); and second, extended necrotic areas with brown discolouration (in cross section) (Fig. 1).

The samples were transported into the laboratory for analysis and were subjected to surface sterilisation according to Fisher et al. (1992). Small pieces (2-5 mm)
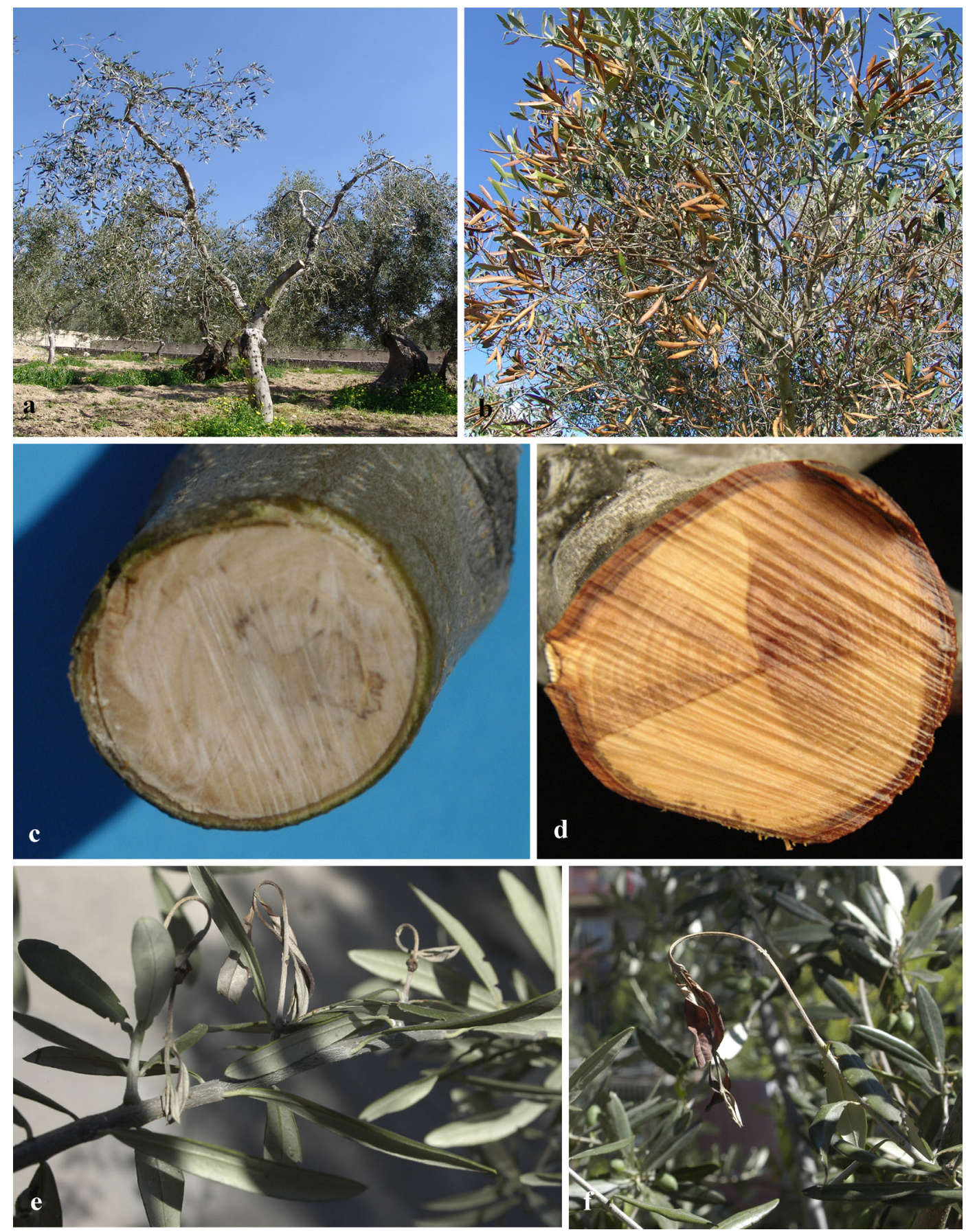

Fig. 1 Disease symptoms observed on olive trees. a Generalised decline and die-back occurred on the tree. b Wilt and browning of leaves. c-d Discolouration of wood evolving in cankers. e-f Wilting of shoots after artificial inoculation caused from Pm. sicilianum 
from discoloured wood of xylematic areas of the base of the trunk, the trunk and the branches were placed on $2 \%$ malt extract (Oxoid Ltd., UK) with $2 \%$ agar (Difco, USA), supplemented with $300 \mathrm{mg} / 1$ streptomycin sulphate (Sigma-Aldrich, USA) (MEAS), and incubated at $23^{\circ} \mathrm{C}\left( \pm 2{ }^{\circ} \mathrm{C}\right)$ in the dark.

All of the fungal colonies isolated were grown until they sporulated, and then a conidial suspension was spread onto agar plates. After 24 to $36 \mathrm{~h}$ of incubation, single germinating conidia were transferred to fresh plates of potato dextrose agar (PDA; $3.9 \%$ potatodextrose agar; Oxoid Ltd., UK). The morphological and culture characteristics were initially used to distinguish all fungal genera and species isolated from symptomatic tissues (De Hoog et al. 2000; Ivic et al. 2010; Phillips et al. 2013; Rumbos 1988). Regarding Phaeoacremonium spp., a detailed morphological study was carried out based on structure and size, phialide type, extent of wart formation, and conidial shape and size (Essakhi et al. 2008; Gams et al. 2007; Mostert et al. 2006; Raimondo et al. 2014). A total of 378 strains of Phaeoacremonium spp. were collected, and the reference strains are maintained in the culture collection of the Department of Science of Agriculture, Food and Environment, of the University of Foggia, Foggia, Italy. The isolation frequencies per olive plant were calculated as the number of tissue portions infected by a given fungus divided by the total samples incubated, and expressed as percentages (Table 1).

DNA isolation, microsatellite primed-PCR profiles

Genomic DNA of all of the isolates identified morphologically as Phaeoacremonium spp. was extracted from fresh mycelia grown on PDA plates in the dark at $25^{\circ} \mathrm{C}$ for $2-$ 3 weeks, according to Carlucci et al. (2013b). The Phaeoacremonium spp. isolates were initially characterised on the basis of their microsatellite primedPCR (MSP-PCR) profiles, as described by Santos and Phillips (2009), using the M13 primer (5'-GAG GGT GGC GGT TCT-3') (Meyer et al. 1993). The DNA banding patterns were analysed using BioNumerics software, version 5.1 (Applied Maths, Kortrijk, Belgium), and using Pearson's correlation coefficients and the unweighted pair group method with arithmetic mean. The reproducibility levels were calculated by comparing the banding profiles obtained for the M13 primer. For this purpose, from any cluster, a number of strains up to $10 \%$ were chosen at random and their profiles were analysed again.

\section{Amplification and sequencing}

A fragment of $600 \mathrm{bp}$ of the $\beta$-tubulin (TUB) gene was amplified using the primers T1 (O'Donnell and Cigelnik 1997) and Bt2b (Glass and Donaldson 1995), and a fragment of $300 \mathrm{bp}$ of the actin $(A C T)$ gene was amplified using the primers ACT-512F and ACT-783R (Carbone and Kohn 1999) for 40 isolates as representative of the MSP-PCR profiles. The PCR reactions were performed according to Raimondo et al. (2014). Ten microlitres of each amplicon were analysed by electrophoresis at $100 \mathrm{~V}$ for $30 \mathrm{~min}$ in $1.5 \%(\mathrm{w} / \mathrm{v})$ agarose gels in $1 \times$ TAE buffer $(40 \mathrm{mM}$ Tris, $40 \mathrm{mM}$ acetate, $2 \mathrm{mM}$ EDTA, $\mathrm{pH}$ 8.0). The gels were stained with ethidium bromide and visualised in a Gel Doc EZ System under UV light (Biorad). The PCR products were purified before DNA sequencing, using Nucleo Spin Extract II purification kits (Macherey-Nagel), according to the manufacturer instructions. Both strands of the PCR products were sequenced by PRIMM srl service (Milan, Italy).

\section{Phylogenetic analysis}

The nucleotide sequences obtained were manually edited using BioEdit v.7.0.9 (http://www.mbio.ncsu.edu/ BioEdit). The $T U B$ and $A C T$ sequences were combined to make it possible to perform multigene analyses, and were aligned using ClustalX version 1.83 (Thompson et al. 1997), with additional sequences retrieved from GenBank (www.ncbi.nlm.gov). A partition homogeneity test of the $T U B$ and $A C T$ alignments was conducted with PAUP v. 4. 0b10 (Swofford 2003) to test pairwise congruence between sequence data sets.

Alignment gaps were treated as missing data, and all of the characters were unordered and of equal weight.

Maximum likelihood analysis was carried out using RAxML on the web-server (Stamatakis et al. 2008) at http://phylobench.vital-it.ch/raxml-bb/index.php, using the gamma model of rate heterogeneity and maximum likelihood search. Maximum parsimony analysis was performed with PAUP using the heuristic search option with 100 random taxa additions and tree bisection and reconstruction as the branch swapping algorithm. Branches of zero length were collapsed and all multiple, equally parsimonious trees were saved. Bootstrap support values were calculated from 100 heuristic search replicates and 10 random taxon 
Table 1 Isolation frequencies of the fungi isolated from internal symptoms consisted with discoloured wood and brown streaking of olive trees

\begin{tabular}{|c|c|c|c|c|c|c|c|c|}
\hline \multirow[t]{3}{*}{ Fungi isolated } & \multicolumn{8}{|c|}{$\%$ fungal isolation frequency (number) } \\
\hline & \multicolumn{4}{|c|}{ Old olive plants } & \multicolumn{4}{|c|}{ Young olive plants } \\
\hline & Base of trunk & Trunk & Branches & Total & Base of trunk & Trunk & Branches & Total \\
\hline Acremonium spp, & $1.9(3)$ & $0.7(1)$ & $1.8(3)$ & 7 & $5.5(8)$ & $7.5(11)$ & $1.9(3)$ & 22 \\
\hline Alternaria alternata & $1.3(2)$ & $0.6(1)$ & $1.3(2)$ & 5 & $3.4(5)$ & $0.0(0)$ & $1.3(2)$ & 7 \\
\hline Aspergillus spp. & $10.7(18)$ & $0.6(1)$ & $0.7(1)$ & 20 & $10.6(15)$ & $0.0(0)$ & $1.4(2)$ & 17 \\
\hline Botryosphaeriaceae & $6.2(10)$ & $18.5(30)$ & $13.6(22)$ & $12.8(62)$ & $0.7(1)$ & $9.4(14)$ & $5.7(8)$ & $5.3(23)$ \\
\hline Cylindrocarpon destructans & $0.7(1)$ & $0.6(1)$ & $0.0(0)$ & 2 & $0.0(0)$ & $0.0(0)$ & $0.0(0)$ & 0 \\
\hline Cytospora oleina & $0.0(0)$ & $0.6(1)$ & $0.0(0)$ & 1 & $0.0(0)$ & $0.0(0)$ & $0.0(0)$ & 0 \\
\hline Lecythophora lignicola & $0.0(0)$ & $1.3(2)$ & $0.0(0)$ & 2 & $0.0(0)$ & $0.0(0)$ & $0.0(0)$ & 0 \\
\hline Microsphaeropsis olivacea & $0.0(0)$ & $1.3(2)$ & $0.0(0)$ & 2 & $0.0(0)$ & $0.0(0)$ & $0.0(0)$ & 0 \\
\hline Penicillium spp. & $1.4(2)$ & $0.0(0)$ & $0.0(0)$ & 2 & $8.0(11)$ & $0.0(0)$ & $0.0(0)$ & 11 \\
\hline Phaeoacremonium spp. & $61.9(102)$ & $67.4(111)$ & $49.6(82)$ & $59.6(295)$ & $12.5(19)$ & $27.7(40)$ & $16.6(24)$ & $19.0(83)$ \\
\hline Phoma incompta & $0.0(0)$ & $0.7(1)$ & $0.0(0)$ & 1 & $0.0(0)$ & $0.0(0)$ & $0.0(0)$ & 0 \\
\hline Pleurostomophora richardsiae & $1.9(3)$ & $0.7(1)$ & $0.0(0)$ & 4 & $0.0(0)$ & $0.7(1)$ & $0.0(0)$ & 1 \\
\hline Micelia sterilia & $9.7(18)$ & $3.4(5)$ & $9.6(16)$ & 39 & $15.3(21)$ & $19.1(27)$ & $14.2(20)$ & 68 \\
\hline No fungi or bacteria & $4.2(6)$ & $4.2(8)$ & $23.4(39)$ & 53 & $45.2(65)$ & $35.7(52)$ & $58.9(86)$ & 203 \\
\hline N. of tissue portions used & 165 & 165 & 165 & 495 & 145 & 145 & 145 & 435 \\
\hline Number of plants analysed & 33 & & & & 29 & & & \\
\hline $\begin{array}{l}\% \text { infected plants from } \\
\text { Phaeoacremonium spp. (number) }\end{array}$ & $100.0(33)$ & & & & $73.3(23)$ & & & \\
\hline
\end{tabular}

additions. The tree length (TL), consistency index (CI), retention index (RI), homoplasy index (HI), and rescaled consistency index (RC) were calculated and the resulting trees were visualised with TreeView, v. 1. 6.6 (Page 1996).

Newly generated sequences were lodged in GenBank (Table 2), and the alignment and trees in TreeBase (www. treebase.org). The sequences of Pleurostomophora richardsiae $(\mathrm{CBS} 270.33$; GenBank: TUB = AY579334, ACT $=$ AY579271) and Wuestneia molokaiensis (CBS 144877; GenBank: TUB = AY579335, ACT = AY579272) were used as outgroups in the phylogenetic analysis.

\section{Pathogenicity tests}

One isolate of each of the following Phaeoacremonium spp. was included in the pathogenicity tests: $P m$. aleophilum (Pm280), Pm. alvesii (Pm83), Pm. italicum (Pm97), Pm. parasiticum (Pm370), Pm. scolyti (Pm25) and Pm. sicilianum (Pm70). The pathogenicity tests were assessed in May 2012 and 2013, on green shoots (0.5-1.2 cm diameter, 30-50 cm long) of 1-2-year-old olive trees of $\mathrm{cv}$. Coratina grown in pots in a greenhouse. Agar plugs (0.3-0.5 cm diam.) taken from 10-day-old cultures grown on AA at $23{ }^{\circ} \mathrm{C}\left( \pm 2{ }^{\circ} \mathrm{C}\right)$ were insert under the bark of small wounds ( $0.4-1.0 \mathrm{~cm}$ length $)$, made on the shoot surface by a sterile scalpel. After inoculation, the wounds were wrapped with wet sterile cotton wool and sealed with Parafilm. The controls were inoculated with sterile agar plugs. Each experiment included 12 replicates per treatment. Four shoots were examined at 60, 120 and 180 days after inoculation, by visual observation and measuring of the lengths of the necrotic lesions that occurred on both the bark and in the inner wood. The means, standard deviations, and maximum and minimum lengths of any wood discolouration were determined. Re-isolations were made from discoloured tissues, and the isolates were identified as described previously, to fulfil Koch's postulates. One-way analysis of variance was performed using Statistica, version 6 (StatSoft, Hamburg, Germany), 
Table 2 Names, collection details and accession numbers of isolates studied

\begin{tabular}{|c|c|c|c|c|c|}
\hline \multirow[t]{2}{*}{ Species } & \multirow[t]{2}{*}{ Isolate number } & \multirow[t]{2}{*}{ Locality in Italy } & \multirow[t]{2}{*}{ Collector } & \multicolumn{2}{|c|}{ GenBank accession numbers } \\
\hline & & & & $\mathrm{ACT}$ & $\beta$-TUB \\
\hline \multirow[t]{7}{*}{ Pm. alvesii } & Pm68 & Cerignola & F. Cibelli & - & - \\
\hline & Pm83 & Cerignola & A. Carlucci & KM201194 & KM201224 \\
\hline & Pm101 & Ortanova & M.L. Raimondo & - & - \\
\hline & Pm199 & Cerignola & M.L. Raimondo & KM201195 & KM201225 \\
\hline & Pm293 & Canosa di Puglia & A. Carlucci & KM201196 & KM201226 \\
\hline & $\operatorname{Pm} 311$ & Cerignola & F. Lops & - & - \\
\hline & Pm339 & Cerignola & A. Carlucci & KM201197 & KM201227 \\
\hline \multirow[t]{4}{*}{ Pm. italicum } & $\operatorname{Pm} 23$ & Cerignola & M.L. Raimondo & KM201205 & KM201212 \\
\hline & $\mathrm{Pm} 48$ & Cerignola & A. Carlucci & KM201206 & KM201213 \\
\hline & Pm97 & Ortanova & A. Carlucci & KM201207 & KM201214 \\
\hline & Pm322 & Cerignola & A. Carlucci & KM201208 & KM201215 \\
\hline \multirow[t]{5}{*}{ Pm. scolyti } & $\operatorname{Pm} 25$ & Cerignola & A. Carlucci & KM201198 & KM201228 \\
\hline & Pm63 & Stornara & F. Lops & - & - \\
\hline & Pm155 & Foggia & M.L. Raimondo & KM201199 & KM201229 \\
\hline & Pm178 & Canosa di Puglia & F. Lops & KM201200 & KM201230 \\
\hline & Pm362 & Cerignola & A. Carlucci & KM201201 & KM201231 \\
\hline \multirow[t]{3}{*}{ Pm. sicilianum } & Pm65 & Cerignola & M.L. Raimondo & KM201202 & KM201209 \\
\hline & Pm70 & Cerignola & A. Carlucci & KM201203 & KM201210 \\
\hline & Pm323 & Canosa di Puglia & F. Lops & KM201204 & KM201211 \\
\hline \multirow[t]{13}{*}{ T. minima (Pm. aleophilum) } & Pm8 & Canosa di Puglia & M.L. Raimondo & - & - \\
\hline & Pm50 & Cerignola & M.L. Raimondo & KM201186 & KM201216 \\
\hline & Pm67 & Cerignola & A. Carlucci & - & - \\
\hline & $\operatorname{Pm} 72$ & Cerignola & A. Carlucci & - & - \\
\hline & $\operatorname{Pm} 92$ & Stornara & A. Carlucci & - & - \\
\hline & Pm115 & Cerignola & M.L. Raimondo & KM201187 & KM201217 \\
\hline & Pm249 & Cerignola & M.L. Raimondo & - & - \\
\hline & $\operatorname{Pm} 255$ & Monte Sant'Angelo & A. Carlucci & KM201188 & KM201218 \\
\hline & $\operatorname{Pm} 272$ & Cerignola & A. Carlucci & - & - \\
\hline & $\operatorname{Pm} 280$ & Cerignola & F. Lops & - & - \\
\hline & Pm330 & Terlizzi & A. Carlucci & KM201189 & KM201219 \\
\hline & Pm355 & Corato & F. Lops & - & - \\
\hline & $\operatorname{Pm} 378$ & Cerignola & A. Carlucci & - & - \\
\hline \multirow[t]{8}{*}{ T. parasitica (Pm. parasiticum) } & $\mathrm{Pm} 43$ & Cerignola & A. Carlucci & - & - \\
\hline & Pm59 & Cerignola & M.L. Raimondo & - & - \\
\hline & Pm88 & Stornara & M.L. Raimondo & KM201190 & KM201220 \\
\hline & Pm163 & Cerignola & A. Carlucci & KM201191 & KM201221 \\
\hline & Pm219 & Cerignola & A. Carlucci & KM201192 & KM201222 \\
\hline & $\operatorname{Pm} 250$ & Monte Sant'Angelo & F. Lops & - & - \\
\hline & Pm321 & Corato & A. Carlucci & - & - \\
\hline & $\operatorname{Pm} 370$ & Terlizzi & A. Carlucci & KM201193 & KM201223 \\
\hline
\end{tabular}

to evaluate the differences in the extension of xylematic discolouration induced by the fungal isolates. Duncan's tests were used for comparisons of treatment means, at $P<0.01$. 


\section{Results}

Isolation and identification of fungal species

A total of 62 symptomatic olive plants were sampled and categorized as old and young plants (33 old, 29 young) (Table 1). All of the old olive plants were positive for Phaeoacremonium spp. infection (100\%), while of the young olive plants, 23 were affected by Phaeoacremonium spp. (73.3\%). A total of 295 isolates (59.6 \%) of Phaeoacremonium spp. were isolated from internal symptoms that consisted of discoloured wood in cross sections of the base of the trunk (61.9\%), the trunk $(67.4 \%)$ and the branches (49.6\%) of all of the old olive trees (Table 1). Lower percentages of isolation of other fungi were obtained from the young olive trees $(19.0 \%)$, and in particular, at 12.5, 27.7 and $16.6 \%$ from the base of the trunk, the trunk and the branch tissues, respectively. Botryosphaeriaceae isolates were often collected in association with the Phaeoacremonium isolates. In particularly, Botryosphaeriaceae spp. were isolated with isolation frequencies of 12.8 and $5.3 \%$ from the old and the young olive trees, respectively. Pl. richardsiae was isolated rarely from older olive plants, and from the wood tissues of base of the trunk (1.9\%) and from the trunk $(0.7 \%)$. No $\mathrm{Pl}$. richardsiae isolate was collected from the branches of the old olive plants. One Pl. richardsiae was collected from the trunk of a young olive plant (Table 1).

Molecular identification and phylogenetic analysis

The MSP-PCR dendrogram of 378 isolates generated six clades (Fig. 2), from which 40 isolates were chosen for sequencing of the $T U B$ and $A C T$ genes (Table 2).

The partition homogeneity test of the TUB and $A C T$ alignments of Phaeoacremonium gave a $p$-value $=0.121$ indicating that the datasets were congruent and could be combined.

The $T U B$ and $A C T$ sequences were generated for 40 isolates selected from the MSP-PCR profiles, and these were aligned with 70 sequences retrieved from GenBank. The dataset consisted of 110 taxa, which included the outgroup taxa ( $P l$. richardsiae, $W$. molokaiensis). After alignment and exclusion of incomplete portions at either end, the dataset consisted of 709 characters (including alignment gaps). Of the 709 characters, 312 were constant, while 60 were variable and parsimony uninformative. Maximum parsimony analysis of the remaining 337 parsimony-informative characters resulted in eight most-parsimonious trees $(\mathrm{TL}=1736 ; \mathrm{CI}=0.441 ; \mathrm{RI}=0.876 ; \mathrm{RC}=0.386$; $\mathrm{HI}=$ $0.559)$. Maximum likelihood analysis resulted in a tree with essentially the same topology as the maximum parsimony trees (TreeBASE S16125) (Fig. 3).

The isolates obtained in this study clustered with six previously published species, namely, Pm. alvesii (seven isolates), Pm. italicum (four isolates), Pm. scolyti (five isolates), Pm. sicilianum (three isolates), Togninia minima (13 isolates) and Togninia parasitica (eight isolates).

On the basis of the data obtained from phylogenetic analyses, it was possible to retrieve the percentages of isolation of each of the above-mentioned species in terms of the total 378 isolates (Table 3). In particular, the species belonging to the Phaeoacremonium genus isolated from the old olive trees consisted of T. minima (23.4 \%), Pm. alvesii (14.6\%), Pm. italicum (7.6\%), T. parasitica (15.7\%), Pm. scolyti (11.1\%) and Pm. sicilianum $(5.7 \%)$, while those from the young olive trees consisted of the following levels, respectively: 8.6, 3.6, 1.5, 6.2, 1.6 and $0.3 \%$ (Table 3).

Pathogenicity tests

The results of the pathogenicity tests were all determined at 60, 120 and 180 days from inoculation (Table 4). All of the six species tested began to produce brown streaking in the wood 60 days from inoculation. The most aggressive Phaeoacremonium spp. was Pm. sicilianum: at 180 days after inoculation, the isolate caused significantly longer regions of brown streaking of $17.4 \mathrm{~cm}$, than the other five species tested. Also, Pm. aleophilum and Pm. italicum showed similar severity, resulting in brown streaking regions of 14.8 to $15.0 \mathrm{~cm}$ after 180 days inoculation. Pm. scolyti caused the shortest regions of brown streaking of $7.8 \mathrm{~cm}$, at 180 days after inoculation. All of the Phaeoacremonium species tested were able to cause wilting of the shoots by 180 days after inoculation, and were re-isolated from symptomatic tissues, thus fulfilling Koch's postulates with percentages of reisolation variable from 83.4 to $95.4 \%$ (Table 4).

\section{Discussion}

On the basis of results obtained from mycological analyses, a direct association was found between 


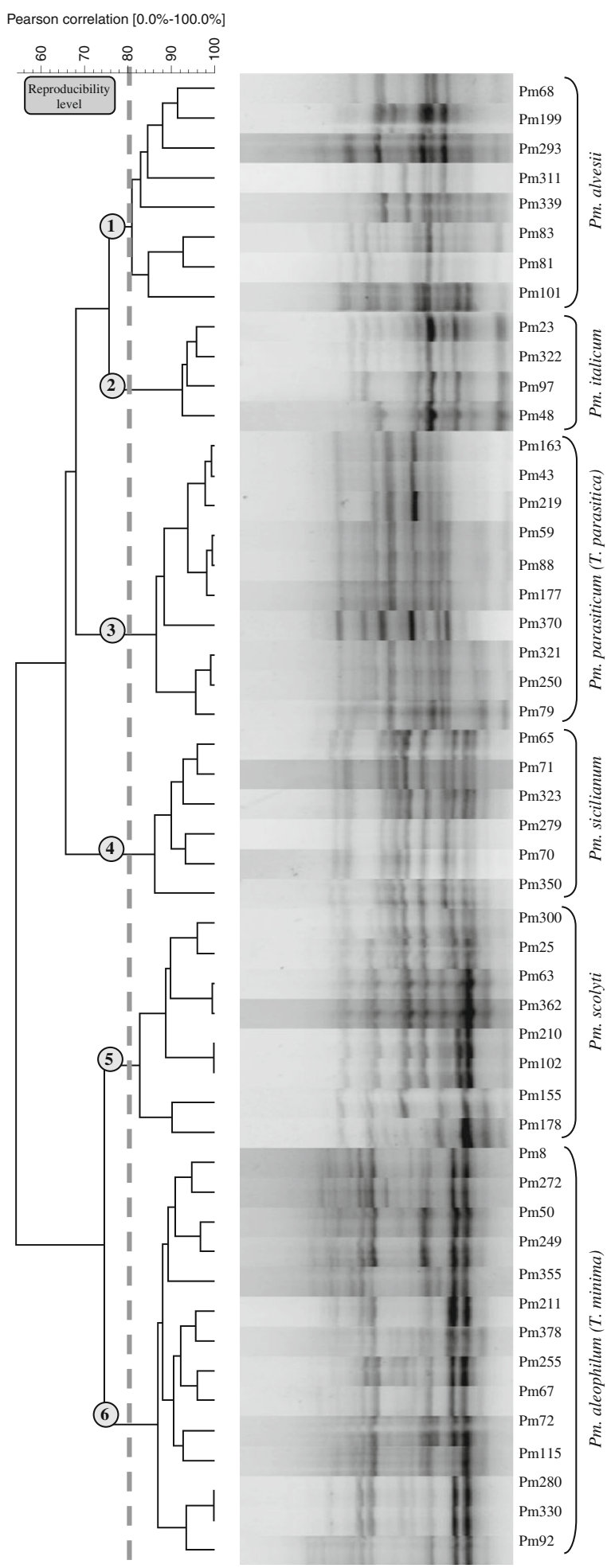

Fig. 2 Consensus cladogram from MSP-PCR profiles obtained with primer M13. The vertical dashed line corresponds to the reproducibility level $(81 \%)$ from which six groups of isolates are inferred (indicated by numbered circles)
Phaeoacremonium spp. and olive decline, which confirmed that these fungi can cause browning of wood and a generalised decline of olive trees. Decline and dieback of sampled olives in southern Italy showed defoliation of the leaves and/or wilting of apical twigs. As these symptoms sometimes involved the whole crown, and at other times just a part of the tree, they were initially attributed to diseases caused by Verticillium dahliae. Indeed, the symptoms observed in the field can be easily confused with Verticillium wilt, as described by Cirulli and Montemurro (1976) and Jiménez-Díaz et al. (2012). The confusion can be avoided if the observations in the fields are not limited to leaves, but also involve the trunk and branches, to ascertain the presence of canker under the bark. Furthermore, $V$. dahliae was never isolated from olive tissues sampled during our surveys. In view of the low isolation frequencies of Lecythophora lignicola, Cytospora oleina, Cylindrocarpon destructans, Microsphaeropsis olivacea, and Phoma incompta from tissues of old trees we consider them to be not significantly relevant as causal agents of above mentioned symptoms.

Little information is available about olive dieback. A recent study by Úrbez-Torres et al. (2013) reported that 18 different fungal species occurred on olive trees showing dieback in California. Among the species identified, Úrbez-Torres et al. (2013) indicated Pm. aleophilum for first time in the United States, with its recovery from olive trunks as a pathogen. Our study on the decline and dieback of olive trees in southern Italy was focused mainly on necrotic xylematic tissues, from which Phaeoacremonium species were isolated most abundantly. In particular, the species identified were Pm. aleophilum, Pm. alvesii, Pm. italicum, Pm. parasiticum, Pm. scolyti and Pm. sicilianum. In Italy, Pm. aleophilum has already been reported as a pathogen of olive trees (Carlucci et al. 2013b; Groenewald et al. 2001), while Pm. parasiticum and Pm. alvesii were reported from olive trees by Nigro et al. (2013). Nevertheless, it was not possible to compare the nucleotide sequences of the Phaeoacremonium spp. described by Nigro et al. (2013) with the species isolated during the present study, because apparently their sequences were not deposited in any DataBank. However, Carlucci et al. (2013b) confirmed the presence of $\mathrm{Pm}$. aleophilum in olives in southern Italy, while Nigro et al. (2013) reported Pm. parasiticum and $P m$. alvesii from the same region. It appears that Nigro et al. (2013) also isolated Pm. 


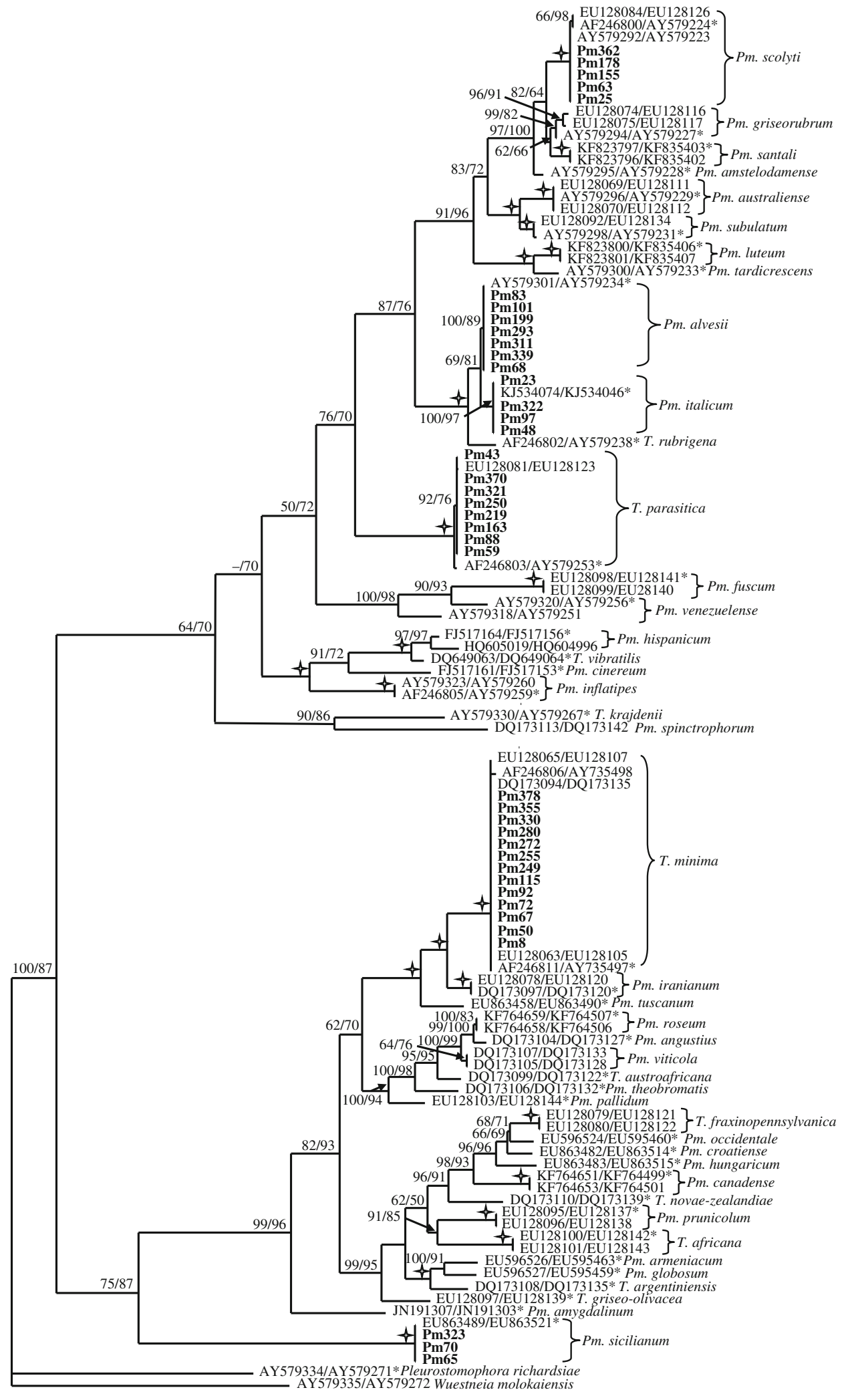


4Fig. 3 One of the eight parsimonious trees obtained from combined alignment of the TUB and $A C T$ gene sequence data with bootstrap support values from Maximum Likelihood/Maximum Parsimony. Bootstrap values of $100 \%$ for Maximum Likelihood/ Maximum Parsimony are indicated with the star-like symbol. Newly generated sequences in this study are highlighted in boldface and listed by their isolate number. Ex-type cultures are marked with an asterisk. Pleurostomophora richardsiae and Wuestneia molokaiensis were included as outgroups

rubrigenum from olive wood. In addition, during our study, we found three other Phaeoacremonium species for first time from olive trees in Italy and worldwide: Pm. italicum, Pm. scolyti and Pm. sicilianum. Pm. italicum was recently reported by Raimondo et al. (2014), as a new Phaeoacremonium species from grapevine in Italy.

To date, including those described in this study, seven Phaeoacremonium species are known from olive trees showing decline, and all of these have previously been reported associated with esca diseases of grapevine. Moreover, of the 43 Phaeoacremonium species known throughout the world, of which 29 have been associated with decline and dieback diseases or with esca of grapevine, and have been isolated from grapevine necrotic wood (Crous et al. 1996; Essakhi et al. 2008; Graham et al. 2009; Gramaje et al. 2009; Larignon and Dubos 1997; Mohammadi and Banihashemi 2012; Morton 1995; Mostert et al. 2006; Raimondo et al. 2014; Sidoti et al. 2000). This indicates that olive and grapevine hosts represent inoculum sources for each other, especially when olive orchards and vineyards are very close, as is frequently the case in Italy. All of these Phaeoacremonium spp. were isolated mainly from browned and cankered tissues situated in the xylem. Together with these Phaeoacremonium species from the same inner tissues of symptomatic olives, $P l$. richardisiae was isolated with a very low isolation frequency. In contrast, in a recent study, Carlucci et al. (2013b) reported that $P l$. richardsiae was abundantly isolated from olive subcortical tissues. This suggests that $P l$. richardsiae is more commonly associated with brown streaking under the bark, while the Phaeoacremonium spp. with wood browning and cankers on inner xylematic tissues. This study indicates the different fungal species that were isolated, including a consistent Botryosphaeriaceae presence, which demonstrates that the aetiology of canker and the subsequent decline and dieback of olive trees is complex. Therefore, it is very difficult to elucidate the real role that any fungal species has in the formation of cankers and/or the decline and dieback that has occurred on olive trees in southern Italy. It cannot be excluded that olive decline and dieback is a result of multiple infections from different fungal and/or bacterial microorganisms. On this point, Carlucci et al. (2013b) indicated that $P l$. richardsiae, N. parvum and $P m$. aleophilum are the fungal pathogens that are responsible for olive decline in southern Italy. Also, Úrbez-Torres et al. (2013) report 18 fungal species that belong to different genera and families involved in olive twig and branch dieback in California. At the same time,

Table 3 Phaeoacremonium species isolated from the discoloured wood of the olive trees

\begin{tabular}{|c|c|c|c|c|c|c|c|c|c|}
\hline \multirow[t]{3}{*}{ Fungi isolated } & \multicolumn{8}{|c|}{$\%$ fungal isolation frequency (number) } & \multirow[t]{3}{*}{ Total } \\
\hline & \multicolumn{4}{|c|}{ Old olive plants } & \multicolumn{4}{|c|}{ Young olive plants } & \\
\hline & $\begin{array}{l}\text { Base of } \\
\text { trunk }\end{array}$ & Trunk & Branches & Total & $\begin{array}{l}\text { Base of } \\
\text { trunk }\end{array}$ & Trunk & Branches & Total & \\
\hline $\begin{array}{l}\text { Pm. aleophilum (Togninia } \\
\text { minima) }\end{array}$ & $7.6(29)$ & $9.3(35)$ & $6.4(24)$ & $23.4(88)$ & $1.8(7)$ & $4.0(15)$ & $2.8(10)$ & $8.6(32)$ & $31.7(120)$ \\
\hline Pm.alvesii & $4.3(16)$ & $6.2(23)$ & $4.1(16)$ & $14.6(55)$ & $0.5(2)$ & $2.2(8)$ & $0.9(3)$ & $3.6(13)$ & $18.0(68)$ \\
\hline Pm.italicum & $2.9(11)$ & $2.3(9)$ & $2.4(9)$ & $7.6(29)$ & $0.7(3)$ & $0.5(2)$ & $0.2(1)$ & $1.5(6)$ & $9.3(35)$ \\
\hline $\begin{array}{l}\text { Pm.parasiticum } \\
\quad(T . \text { parasitica })\end{array}$ & $5.5(21)$ & $5.4(20)$ & $4.7(18)$ & $15.7(59)$ & $1.3(5)$ & $2.9(11)$ & $2.0(8)$ & $6.2(24)$ & $22.0(83)$ \\
\hline Pm. scolyti & $4.3(16)$ & $4.1(16)$ & $2.8(10)$ & $11.1(42)$ & $0.5(2)$ & $0.7(3)$ & $0.4(2)$ & $1.6(7)$ & $12.9(49)$ \\
\hline Pm. sicilianum & $2.5(9)$ & $2.0(8)$ & $1.3(5)$ & $5.7(22)$ & $0.0(0)$ & $0.3(1)$ & $0.0(0)$ & $0.3(1)$ & $6.1(23)$ \\
\hline Total & $27.0(102)$ & $29.4(111)$ & $49.6(82)$ & $78.1(295)$ & $4.8(19)$ & $10.6(40)$ & $6.3(24)$ & $21.9(83)$ & $100.0(378)$ \\
\hline
\end{tabular}


Table 4 Pathogenicity tests carried out with six Phaeacremonium species inoculated on young olive shoots (cv. Coratina)

\begin{tabular}{|c|c|c|c|c|c|c|c|c|c|c|c|c|}
\hline \multirow[t]{3}{*}{ Fungal species } & \multirow[t]{3}{*}{ Isolate ID } & \multicolumn{11}{|c|}{ Brown streaking length $(\mathrm{cm})$, after: } \\
\hline & & \multicolumn{3}{|l|}{60 days } & \multicolumn{3}{|c|}{120 days } & \multicolumn{3}{|c|}{180 days } & \multicolumn{2}{|c|}{ Re-isolation } \\
\hline & & Mean & SD & 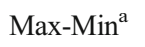 & Mean & SD & Max-Min & Mean & $\mathrm{SD}$ & Max-Min & $(\%)$ & Dead shoot \\
\hline Control & & $0.0 \mathrm{~A}^{\mathrm{b}}$ & - & - & $0.0 \mathrm{~A}$ & - & - & $0.0 \mathrm{~A}$ & - & - & - & No \\
\hline Pm. aleophilum & $\operatorname{Pm} 280$ & $1.2 \mathrm{C}$ & 0.4 & $2.2-0.4$ & $4.7 \mathrm{C}$ & 1.2 & $7.5-2.9$ & $15.0 \mathrm{D}$ & 2.9 & $19.3-8.5$ & 92.0 & Yes \\
\hline Pm. alvesi & Pm83 & $0.8 \mathrm{BC}$ & 0.5 & $1.8-0.2$ & $2.6 \mathrm{~B}$ & 0.6 & $3.3-1.5$ & $10.7 \mathrm{C}$ & 1.8 & $13.1-6$ & 94.5 & Yes \\
\hline Pm. italicum & Pm97 & $1.3 \mathrm{C}$ & 0.7 & $2.8-0.3$ & $4.9 \mathrm{C}$ & 1.5 & $7.5-2.4$ & $14.8 \mathrm{D}$ & 1.8 & $17.4-8.9$ & 95.4 & Yes \\
\hline Pm. parasiticum & $\operatorname{Pm} 370$ & $1.0 \mathrm{BC}$ & 0.5 & $2.0-0.2$ & $3.4 \mathrm{~B}$ & 0.6 & $4.4-1.8$ & $12.5 \mathrm{C}$ & 2.3 & $17.4-6.5$ & 89.9 & Yes \\
\hline Pm. scolyti & $\operatorname{Pm} 25$ & $0.6 \mathrm{~B}$ & 0.3 & $1.3-0.2$ & $2.6 \mathrm{~B}$ & 0.7 & $4.4-1.8$ & $7.8 \mathrm{~B}$ & 1.3 & $11.6-6.2$ & 83.4 & Yes \\
\hline Pm. sicilianum & $\operatorname{Pm} 70$ & $1.3 \mathrm{C}$ & 0.7 & $2.8-0.35$ & $6.3 \mathrm{D}$ & 1.3 & $8.3-3.2$ & $17.4 \mathrm{E}$ & 2.6 & $22.1-12.2$ & 92.3 & Yes \\
\hline
\end{tabular}

${ }^{a}$ Maximum and minimum values detected on the basis of 12 observations

${ }^{\mathrm{b}}$ Values followed by a different capital letter in each column are significantly different according to Duncan's test $(P<0.01)$

a severe disease has been reported from in a large part of southern Apulia that is affecting young and centuriesold olive trees, Xylella fastidiosa, a xylem-limited quarantine bacterium that affects young and old olive trees, has been implicated as a cause of this disease (Carlucci et al. 2013a; Saponari et al. 2013).

This study confirms that Phaeoacremonium spp. are tracheomycotic fungi able to cause discolouration in xylem tissues. Moreover, since they were isolated with higher IFs from older olive plants than from younger ones, we consider that these fungi are able to infect olive trees through their life, probably via pruning wounds. This could explain the reason for the higher isolation frequencies from xylem tissues in branches of older olive trees.

Open Access This article is distributed under the terms of the Creative Commons Attribution License which permits any use, distribution, and reproduction in any medium, provided the original author(s) and the source are credited.

\section{References}

Agosteo, G. E. (2011). Olive diseases, a historical account. Chapter 2. In G. Magnano di San Lio (Ed.), Olive diseases and disorders (pp. 23-42). Kerala: Transworld Research Network.

Braun, U. (1993). Taxonomic notes on some species of Cercospora complex (III). Mycotaxon, 48, 275-298.
Carbone, I., \& Kohn, L. M. (1999). A method for designing primer sets for speciation studies in filamentous Ascomycetes. Mycologia, 91, 553-556.

Carlucci, A., Lops, F., Marchi, G., Mugnai, L., \& Surico, G. (2013a). Has Xylella fastidiosa "chosen" olive trees to establish in the Mediterranean basin? Phytopathologia Mediterranea, 52, 541-544.

Carlucci, A., Raimondo, M. L., Cibelli, F., Phillips, A. J. L., \& Lops, F. (2013b). Pleurostomophora richardsiae, Neofusicoccum parvum and Phaeoacremonium aleophilum associated with a decline of olives in southern Italy. Phytopathologia Mediterranea, 52, 517-527.

Chattaoui, M., Rhouma, A., Krid, S., Ali Triki, M., Moral, J., Msallem, M., \& Trapero, A. (2011). First report of fruit rot of olives caused by Botryosphaeria dothidea in Tunisia. Plant Disease, 95, 770.

Cirulli, M., \& Montemurro, G. (1976). A comparison of pathogenic isolates of Verticillium dahliae and sources of resistance in olive. Agriculturae Conspectus Scientificus, 39, 469-476.

Crous, P. W., Gams, W., Wingfield, M. J., \& Van Wyk, P. S. (1996). Phaeoacremonium gen. nov. associated with wilt and decline diseases of woody hosts and human infections. Mycologia, 88, 786-796.

De Hoog, G. S., Guarro, J., Gené, J., \& Figueras, M. J. (2000). Atlas of clinical fungi. Utrecht: Centraalbureau voor Schimmelcultures.

Essakhi, S., Mugnai, L., Crous, P. W., Groenewald, J. Z., \& Surico, G. (2008). Molecular and phenotypic characterization of novel Phaeoacremonium species associated with Petri disease and esca of grapevine. Persoonia, 21, 119-134.

Fisher, P. J., Petrini, O., Petrini, L. E., \& Descals, E. (1992). A preliminary study of fungi inhabiting xylem and whole stems of Olea europaea. Sydowia, 44, 117-121. 
Food and Agriculture Organisation of the United Nations (FAO). FAOSTAT (c) FAO Statistics Division. Retrieved 15 January 2013 from http://faostat.fao.org/default.aspx

Galili, E., Stanley, D. J., Sharvit, J., \& Weinstein-Evron, M. (1997). Evidence for earliest olive-oil production in submerged settlements off the Carmel coast, Israel. Journal of Archaeological Science, 24, 1141-1150.

Gams, W., Verkleij, G. J. M., \& Crous, P. W. (Eds.). (2007). CBS course of mycology. Utrecht: Centraalbureau voor Schimmelcultures.

Glass, N. L., \& Donaldson, G. C. (1995). Development of primer sets designed for use with the PCR to amplify conserved genes from filamentous infection due to Phaeoacremonium spp. Journal of Clinical Microbiology, 41, 1332-1336.

Graham, A. B., Johnston, P. R., \& Weir, B. S. (2009). Three new Phaeoacremonium species on grapevines in New Zealand. Australasian Plant Pathology, 38, 505-513.

Gramaje, D., Armengol, J., Mohammadi, H., Banihashemi, Z., \& Mostert, L. (2009). Novel Phaeoacremonium species associated with Petri disease and esca of grapevines in Iran and Spain. Mycologia, 101, 920-929.

Groenewald, M., Kang, J. C., Crous, P. W., \& Gams, W. (2001). ITS and beta-tubulin phylogeny of Phaeoacremonium and Phaeomoniella. Mycological Research, 105, 651-657.

Ivic, D., Ivanovic, A., Milicevic, T., \& Cvjetkovic, B. (2010). Shoot necrosis of olive caused by Phoma incompta, a new disease of olive in Croatia. Phytopathologia Mediterranea, 49, 414-416.

Jiménez-Díaz, R. M., Cirulli, M., Bubici, G., Jiménez-Gasco, M. M., Antoniou, P. P., \& Eleftherios, C. T. (2012). Verticillium wilt, a major threat to olive production: current status and future prospects for its management. Plant Disease, 96, 304-329.

Kaliterna, K., Ivic, I., Bencic, D., \& Mesic, A. (2012). First report of Diplodia seriata as causal agent of olive dieback in Croatia. Plant Disease, 96, 290.

Larignon, P., \& Dubos, B. (1997). Fungi associated with esca disease in grapevine. European Journal of Plant Pathology, 103, 147-157.

Meyer, W., Mitchell, T. G., Freedman, E. Z., \& Vilgalys, R. (1993). Hybridization probes for conventional DNA fingerprinting used as single primers in the polymerase chain reaction to distinguish strains of Cryptococcus neoformans. Journal of Clinical Microbiology, 31, 2274-2280.

Mohammadi, H., \& Banihashemi, Z. (2012). First report of Phaeoacremonium inflatipes and Phaeoacremonium mortoniae associated with grapevine petri disease in Iran. Journal of Agricultural Science and Technology, 14, 1405-1414.

Moral, J., Luque, F., \& Trapero, A. (2008). First report of Diplodia seriata, the anamorph of "Botryosphaeria" obtusa, causing fruit rot of olive in Spain. Plant Disease, 92, 311.

Moral, J., Muñoz-Díez, C., González, N., Trapero, A., \& Michailides, T. (2010). Characterization and pathogenicity of Botryosphaeriaceae species collected from olive and other hosts in Spain and California. Phytopathology, 100, 1340-1351.

Morton, L. (1995). Mystery diseases hit young vines. Wines \& Vines, 76, 46-47.

Mostert, L., Groenewald, J. Z., Summerbell, R. C., Gams, W., \& Crous, P. W. (2006). Taxonomy and pathology of Togninia (Diaporthales) and its Phaeoacremonium anamorphs. Studies in Mycology, 54, 1-115.
Neef, R. (1990). Introduction, development and environmental implications of olive culture: The evidence from Jordan. In S. Bottema, G. Entjes-Nieborg, \& W. Van Zeist (Eds.), Man's role in the shaping of the eastern Mediterranean landscape (pp. 295-306). Rotterdam: Balkema.

Nigro, F., Boscia, D., Antelmi, I., \& Ippolito, A. (2013). Fungal species associated with a severe decline of olive in southern Italy. Journal of Plant Pathology, 95(3), 668.

O’Donnell, K., \& Cigelnik, E. (1997). Two divergent intragenomic rDNA ITS2 types within a monophyletic lineage of the fungus Fusarium are nonorthologous. Molecular Phylogenetics and Evolution, 7, 103-116.

Page, R. D. (1996). TreeView: an application to display phylogenetic trees on personal computers. Computer Applications in the Biosciences, 12, 357-358.

Phillips, A. J. L., Alves, A., Correia, A., \& Luque, J. (2005). Two new species of Botryosphaeria with brown, 1 -septate ascospores and Dothiorella anamorphs. Mycologia, 97, 513-529.

Phillips, A. J. L., Alves, A., Abdollahzadeh, J., Slippers, B., Wingfield, M. J., Groenewald, J. Z., \& Crous, P. W. (2013). The Botryosphaeriaceae: genera and species known from culture. Studies in Mycology, 76, 51-167.

Raimondo, M. L., Lops, F., \& Carlucci, A. (2014). Phaeoacremonium italicum sp. nov., a new species associated with esca of grapevine in southern Italy. Mycologia, 106, 1119-1126.

Rhouma, A., Triki, M. A., Krid, S., \& Masallem, M. (2010). First report of a Branch dieback of olive trees in Tunisia caused by a Phoma sp. Plant Disease, 94, 636.

Romero, M. A., Sánchez, M. E., \& Trapero, A. (2005). First report of Botryosphaeria ribis as a branch dieback pathogen of olive trees in Spain. Plant Disease, 89, 208.

Rumbos, I. C. (1988). Cytospora oleina causing canker and dieback of olive in Greece. Plant Pathology, 37, 441-444.

Rumbos, I. C. (1993). Dieback symptoms on olive trees caused by the fungus Eutypa lata. Bulletin OEPP/EPPO Bullettin, 23, 441-445.

Salavert, A. (2008). Olive cultivation and oil production in Palestine during the early Bronze Age (3500-2000 B.C.): the case of Tel Yarmouth, Israel. Vegetation History and Archaeobotany, 17, S53-S61.

Santos, J. M., \& Phillips, A. J. L. (2009). Resolving the complex of Diaporthe (Phomopsis) species occurring on Foeniculum vulgare in Portugal. Fungal Diversity, 34, 111-125.

Saponari, M., Boscia, D., Nigro, F., \& Martelli, G. P. (2013). Identification of DNA sequences related to Xylella fastidiosa in oleander, almond and olive trees exhibiting leaf scorch symptoms in Apulia (southern Italy). Journal of Plant Pathology, 95, 659-668.

Sidoti, A., Buonocore, E., Serges, T., \& Mugnai, L. (2000). Decline of young grapevines associated with Phaeoacremonium chlamydosporium in Sicily (Italy). Phytopathologia Mediterranea, 39, 87-91.

Stamatakis, A., Hoover, P., \& Rougemont, J. (2008). A rapid bootstrap algorithm for the RaxML-VI-HPC web servers. Systematic Biology, 57, 758-771.

Swofford, D. L. (2003). PAUP*: Phylogenetic Analysis Using Parsimony (*and other methods). Version 4. Sunderland: Sinauer Associates. 
Talhinhas, P., Sreenivasaprasad, S., Neves-Martins, J., \& Oliveira, H. (2005). Molecular and phenotypic analyses reveal association of diverse Colletotrichum acutatum groups and a low level of C. gloeosporioides with olive anthracnose. Applied and Environmental Microbiology, 71, 2987-2998.

Terral, J. F., Alonso, N., Capdevila, R. B. I., Chatti, N., Fabre, L., Fiorentino, G., Marinval, P., Jorda, G. P., Prada, B., Rovira, N., \& Alibert, P. (2004). Historical biogeography of olive domestication (Olea europaea L.) revealed by geometrical morphometry applied to biological and archaeological material. Journal of Biogeography, 31, 63-77.

Thompson, J. D., Gibson, T. J., Plewniak, F., Jeanmougin, F., \& Higgins, D. G. (1997). The ClustalX windows interface: flexible strategies for multiple sequence alignment aided by quality analysis tools. Nucleic Acids Research, 25, 4876-4882.
Tosi, L., \& Natalini, G. (2009). First report of Eutypa lata causing dieback of olive trees in Italy. Plant Pathology, 58, 398.

Tosi, L., \& Zazzerini, A. (1994). Phoma incompta a new olive parasite in Italy. Petria, 4, 161-170.

Úrbez-Torres, J. R., Peduto, F., Vossen, P. M., Krueger, W. H., \& Gubler, W. D. (2013). Olive twig and branch dieback: etiology, incidence, and distribution in California. Plant Disease, 97, 231-244.

Van Zeist, W. (1980). Aperçu sur la diffusion des végétaux cultivés dans la région méditerranéenne in Colloque de la Fondation $\mathrm{L}$ Emberger « La mise en place, l'évaluation et la caractérisation de la flore et de la végétation circum-méditerranéenne ", Montpellier, Naturalia Monspeliensa, 129-145.

Zohary, D., \& Spiegel-Roy, P. (1975). Beginnings of fruit growing in the old world. Science, 187, 319-327. 